American Journal of Agricultural and Biological Sciences 5 (3): 256-260, 2010

ISSN 1557-4989

(C) 2010 Science Publications

\title{
Effect of Replacement of Soybean meal by Dried Tomato Pomace on Rumen Fermentation and Nitrogen Metabolism in Beef Cattle
}

\author{
${ }^{1} \mathrm{C}$. Yuangklang, ${ }^{1} \mathrm{~K}$. Vasupen, ${ }^{1} \mathrm{~S}$. Wongsuthavas, ${ }^{1}$ S. Bureenok, \\ ${ }^{1}$ P. Panyakaew, ${ }^{2}$ A. Alhaidary, ${ }^{2}$ H.E. Mohamed and ${ }^{1,2}$ A.C. Beynen \\ ${ }^{1}$ Department of Animal Science, Faculty of Natural Resources, \\ Rajamangala University of Technology-Isan, Sakon Nakhon Campus, \\ Phang Khon, Sakon Nakhon, 47160 Thailand \\ ${ }^{2}$ Department of Animal Production, College of Food and Agricultural Sciences, \\ King Saud University, Riyadh 11451, Kingdom of Saudi Arabia
}

\begin{abstract}
Problem statement: Dried tomato pomace may be considered as an alternative feedstuff in ruminant nutrition. The limited literature data that are available so far may be interpreted as indirect and suggestive evidence for diminished ruminal fermentation and bacterial synthesis after substitution of dried tomato pomace for soybean meal. Approach: Rumen-fistulated beef steers were used to address the questions whether the replacement of soybean meal by dried tomato pomace would affect feed intake, rumen fermentation and nitrogen metabolism. In a feeding trial with Latin-square design, the steers were fed total mixed rations containing either $3.2,8.0$ or $11.2 \%$ dried tomato pomace. Results: The replacement of dietary soybean meal by dried tomato pomace did not affect feed intake, but was found to change various indices of rumen fermentation. Increasing intakes of dried tomato pomace caused increasing ruminal $\mathrm{pH}$ values and ammonia concentrations in a dose-dependent fashion, but concentrations of volatile fatty acids and number of ruminal bacteria were left unchanged. Higher dietary inclusion levels of tomato pomace produced a linear, dose-related increase in blood urea concentrations. Apparent, total gastro-intestinal tract digestibilities of neutral and acid-detergent fiber were not influenced by tomato pomace. The feeding of tomato pomace raised fecal nitrogen excretion and lowered urinary nitrogen excretion. Conclusion: Substitution of tomato pomace for soybean meal influences rumen fermentation and nitrogen metabolism in beef cattle, but the impact on practical ruminant production cannot yet be assessed.
\end{abstract}

Key words: Beef cattle, soybean meal, tomato pomace, rumen fermentation, nitrogen utilization

\section{INTRODUCTION}

To reduce the feed costs of animal production, it can be advantageous to replace imported feedstuffs by those produced locally. To evaluate the possible use of an alternative feedstuff, its nutritional value has to be known. In the North-East of Thailand there is abundant availability of dried tomato pomace which is a byproduct of the processing of tomato paste. Dried tomato pomace contains $20-25 \%$ crude protein, $9-12 \%$ crude fat and $57-67 \%$ neutral detergent fiber. There are indications that tomato pomace may be used in ruminant nutrition.

It has been reported that the feeding of corn silage mixed with wet tomato pomace to dairy cows left unchanged the production and composition of milk
(Weiss et al., 1997). Incorporation of tomato pomace instead of soybean protein in the barley-based ration of lambs did not affect growth performance and nitrogen retention (Fondevila et al., 1994). In beef cattle, the feeding of dried tomato pomace as sole source of roughage increased body-weight gain when compared to either hay or fresh grass (Yuangklang et al., 2006).

It would appear that dried tomato pomace in the ration can support ruminant production. However, less favorable effects of tomato pomace have described also. In goats, replacement of soybean meal by dried tomato pomace produced an increase in the ammonia concentration and $\mathrm{pH}$ of rumen contents (Yuangklang et al., 2007). This could point at diminished ruminal fermentation and bacterial protein synthesis (Satter and Slyter, 1974). In dairy cows,

Corresponding Author: C. Yuangklang, Department of Animal Science, Faculty of Natural Resources, Rajamangala University of Technology-Isan, Phang Khon, 47160 Sakon Nakhon, Thailand Tel: +66-42771460 Fax +66-42771460 
replacement of soybean meal by dried tomato pomace did not alter milk production, but it decreased milk protein concentration (Yuangklang et al., 2005). The observed decrease in milk protein could be caused by depressed bacterial protein synthesis in the rumen.

Until now there only was indirect and suggestive evidence for diminished ruminal fermentation and bacterial synthesis after substitution of dried tomato pomace for soybean meal (Yuangklang et al., 2005; 2007). Therefore, the objective of the present experiment was to investigate the effects of replacement of soybean meal by dried tomato pomace on voluntary feed intake, rumen fermentation and nitrogen metabolism in beef steers fitted with a rumen fistula.

\section{MATERIALS AND METHODS}

Animals and treatments: Four permanently fistulated beef steers aged about 3.5 years were used in a feeding trial with $4 \times 4$ Latin-square design. The initial body weight of the steers was $370 \pm 38 \mathrm{~kg}$ (mean \pm SD). Each feeding period lasted 21 days. During the first 14 days of each period voluntary feed intake was measured. The animals were housed individually in pens. For the last 7 days of each period, the steers were transferred to metabolism crates. There were two days for adaptation and 5 days for separate and quantitative collection of urine and feces.

The experimental, total mixed rations are given in Table 1. Diet A did not contain tomato pomace, the inclusion levels of soybean meal and cassava chips being 40 and $11.2 \%$. To formulate diets B, C and D, increasing amounts of tomato pomace were added at the expense of soybean meal and cassava chips so that crude protein concentration of the four rations were kept constant. Diets B, C and D contained 3.2, 8.0 and $11.2 \%$ dried tomato pomace, respectively.

Chemical analyses: Diet and feces samples were analyzed for the contents of dry matter, crude ash, crude fat and crude protein, Neutral Detergent Fiber (NDF) and Acid Detergent Fiber (ADF) as described earlier (Jansen et al., 2000).

Ruminal fluid samples (approximately $500 \mathrm{~mL}$ ) were collected through the rumen fistula at $4 \mathrm{~h}$-post morning feeding on the last day of each period. The $\mathrm{pH}$ of the ruminal fluid was measured immediately using a portable $\mathrm{pH}$ meter. The samples were then filtered through four layers of cheese cloth. For the analysis of $\mathrm{NH}_{3}-\mathrm{N}, 10 \mathrm{~mL}$ of $50 \% \mathrm{H}_{2} \mathrm{SO}_{4}$ solution was added to $100 \mathrm{~mL}$ of ruminal fluid. The mixture was centrifuged at
$16,000 \times \mathrm{g}$ for 15 minutes and the supernatant was stored at $-20^{\circ} \mathrm{C}$ prior to $\mathrm{NH}_{3}-\mathrm{N}$ measurement (Hristov et al., 2000). Volatile fatty acids were analyzed by HPLC (model RF-10AXmugiL, Shimadzu, Japan) according to Zinn and Owens (1986). A portion of ruminal fluid was fixed with $10 \%$ formalin solution in normal saline (Purser and Moir, 1966) and stored at $4{ }^{\circ} \mathrm{C}$. Total direct counts of bacteria and protozoa were made using the methods of Purser and Moir (1966) with the use of a hemocytometer.

A blood sample was taken from the jugular vein at the same time as ruminal fluid sampling. The samples were centrifuged $500 \times \mathrm{g}$ for $10 \mathrm{~min}$ and the supernatants were stored at $-20^{\circ} \mathrm{C}$ until the analysis of blood urea-N (Crocker, 1967).

Calculations and statistical analysis: The apparent nutrient digestibility was expressed as percentage of intake and computed as (intake-output with feces) $\times$ intake $^{-1} \times 100 \%$.

The data are presented as treatment means and SEM for four animals. Statistical analysis of the data was done using a computer program (SPSS for windows 9.0, SPSS Inc., Chicago, 1998). Linear, quadratic or cubic regressions were tested for the actual level of dried tomato pomace in the ration. None of the variables showed statistically, significant quadratic or cubic effects of the level of dietary tomato pomace. Significant differences between treatments were identified using Duncan's multiple range test. The level of statistical significance was pre-set at $\mathrm{p}<0.05$.

Table 1: Ingredient and analyzed composition of the experimental total mixed rations

\begin{tabular}{|c|c|c|c|c|}
\hline \multirow[b]{2}{*}{ Ingredients $(\mathrm{g})$} & \multicolumn{4}{|c|}{ Experimental ration } \\
\hline & A & B & $\mathrm{C}$ & $\mathrm{D}$ \\
\hline Cassava chips & 11.2 & 8.0 & 3.2 & 0.0 \\
\hline Soybean meal & 40.0 & 39.8 & 39.5 & 39.3 \\
\hline Dried tomato pomace & 0.0 & 3.2 & 8.0 & 11.2 \\
\hline Urea & 2.0 & 2.2 & 2.5 & 2.7 \\
\hline Constant components ${ }^{1}$ & 46.8 & 46.8 & 46.8 & 46.8 \\
\hline Total & 100.0 & 100.0 & 100.0 & 100.0 \\
\hline \multicolumn{5}{|c|}{ Chemical composition (\%) } \\
\hline Dry matter & 93.7 & 93.4 & 93.5 & 93.8 \\
\hline Ash & 9.0 & 9.0 & 9.1 & 9.2 \\
\hline Crude protein & 15.4 & 15.2 & 15.3 & 15.3 \\
\hline Crude fat & 4.0 & 3.9 & 4.0 & 4.0 \\
\hline Neutral detergent fiber & 40.6 & 38.3 & 42.1 & 41.4 \\
\hline Acid detergent fiber & 28.9 & 29.6 & 28.4 & 28.6 \\
\hline
\end{tabular}




\section{RESULTS}

Table 2 shows that there was no diet effect on dry matter intake. The replacement of soybean meal by dried tomato pomace did not affect the apparent digestibilities of dry matter, organic matter, crude fat, $\mathrm{NDF}$ and ADF. When the rations with dried tomato pomace were fed, the digestibility of crude protein was significantly reduced, but there was no dose-response relationship.

Nitrogen intake was similar for the four dietary treatments (Table 3). Increasing dietary inclusion levels of tomato pomace were associated with increasing amounts of fecal nitrogen excretion and deceasing amounts of urinary nitrogen. The effects on fecal and urinary nitrogen excretion showed a significant linear trend for dose dependency. Nitrogen retention, expressed as percentage of nitrogen intake was not affected by dietary treatment.

The concentration of blood urea-nitrogen was raised by ingestion of tomato pomace in a linear, dosedependent fashion (Table 4). Dried tomato pomace in the ration significantly raised the $\mathrm{pH}$ and $\mathrm{NH}_{3}$-nitrogen concentration of the ruminal fluid. Both effects showed a significant linear trend. The total amount of volatile fatty acids and the percentages of acetate, propionate and butyrate were not influenced by the dietary treatments. There was no effect of the amount of dried tomato pomace in the diet on the numbers of bacteria and protozoa in ruminal fluid.

Table 2: Feed intake and apparent nutrient digestibility for the dietary treatments

\begin{tabular}{|c|c|c|c|c|c|c|}
\hline & \multicolumn{6}{|c|}{ Dietary treatment } \\
\hline & A & $\mathrm{B}$ & $\mathrm{C}$ & $\mathrm{D}$ & SEM & $\mathrm{L}$ \\
\hline $\begin{array}{l}\text { Feed intake, } \mathrm{kg} \text { dry matter day }{ }^{-1} \\
\text { Nutrient digestibility, } \% \text { of intake }\end{array}$ & 6.97 & 6.89 & 6.80 & 6.77 & 1.55 & NS \\
\hline Dry matter & 68.9 & 67.5 & 66.8 & 66.2 & 0.67 & NS \\
\hline Organic matter & 72.1 & 70.4 & 69.2 & 68.8 & 0.45 & NS \\
\hline Crude protein & $78.4^{\mathrm{a}}$ & $74.7^{\mathrm{b}}$ & $74.9^{\mathrm{b}}$ & $75.8^{\mathrm{b}}$ & 0.32 & NS \\
\hline Crude fat & 80.7 & 81.6 & 82.6 & 83.2 & 0.57 & NS \\
\hline Neutral detergent fiber & 55.8 & 56.7 & 57.7 & 58.9 & 0.54 & NS \\
\hline Acid detergent fiber & 47.8 & 46.9 & 48.3 & 49.2 & 0.65 & NS \\
\hline
\end{tabular}

Table 3: Ruminal pH, ammnonia-nitrogen, volatile fatty acids and microbial counts and Blood-Urea Nitrogen (BUN) for the dietary treatments

\begin{tabular}{|c|c|c|c|c|c|c|}
\hline & \multicolumn{6}{|c|}{ Dietary treatment } \\
\hline & A & $\mathrm{B}$ & $\mathrm{C}$ & $\mathrm{D}$ & SEM & $\mathrm{L}$ \\
\hline Rumen $\mathrm{pH}$ & $6.51^{\mathrm{b}}$ & $6.66^{\mathrm{b}}$ & $6.74^{\mathrm{a}}$ & $6.85^{\mathrm{a}}$ & 0.02 & $*$ \\
\hline Rumen $\mathrm{NH}_{3}-\mathrm{N}(\mathrm{mg} \%)$ & $13.6^{\mathrm{c}}$ & $14.9^{\mathrm{bc}}$ & $16.8^{\mathrm{ab}}$ & $18.3^{\mathrm{a}}$ & 0.03 & $*$ \\
\hline Total VFA (mM) & 79.7 & 76.8 & 77.4 & 78.1 & 0.56 & * \\
\hline Acetate $(\%)$ & 67.8 & 65.4 & 65.8 & 66.2 & 0.79 & NS \\
\hline Propionate $(\%)$ & 26.7 & 24.7 & 24.2 & 23.8 & 0.64 & NS \\
\hline Butyrate $(\%)$ & 6.50 & 9.90 & 10.0 & 10.0 & 0.83 & NS \\
\hline Bacteria $\times 10^{9} \mathrm{CFU} \mathrm{mL} \mathrm{m}^{-1}$ & 6.8 & 5.5 & 5.5 & 6.0 & 0.07 & NS \\
\hline Protozoa $\times 10^{5} \mathrm{CFU} \mathrm{\textrm {mL } ^ { - 1 }}$ & 5.7 & 4.5 & 4.0 & 4.0 & 0.83 & NS \\
\hline BUN (mg\%) & $10.6^{\mathrm{b}}$ & $11.4^{\mathrm{ab}}$ & $12.6^{\mathrm{a}}$ & $12.8^{\mathrm{a}}$ & 0.02 & $*$ \\
\hline
\end{tabular}

Statistical analysis: L: Linear effect; NS: Not Significant; *: $p<0.05$; Means in the same row not sharing the same superscript are significantly different

Table 4: Nitrogen balances for the dietary treatments

\begin{tabular}{|c|c|c|c|c|c|c|}
\hline & \multicolumn{6}{|c|}{ Dietary treatment } \\
\hline & A & B & $\mathrm{C}$ & $\mathrm{D}$ & SEM & $\mathrm{L}$ \\
\hline$\overline{\mathrm{N} \text { intake }\left(\mathrm{g} \mathrm{day}^{-1}\right)}$ & 171.7 & 167.6 & 166.5 & 165.7 & 5.37 & NS \\
\hline Fecal N $\left(\mathrm{g} \mathrm{day}^{-1}\right)$ & $34.7^{\mathrm{b}}$ & $35.1^{\mathrm{ab}}$ & $36.4^{\mathrm{ab}}$ & $38.1^{\mathrm{a}}$ & 0.49 & $*$ \\
\hline Urinary $\mathrm{N}\left(\mathrm{g} \mathrm{day}^{-1}\right)$ & $120.2^{\mathrm{a}}$ & $116.7^{\mathrm{b}}$ & $113.6^{\mathrm{b}}$ & $112.3^{\mathrm{b}}$ & 0.86 & $*$ \\
\hline $\mathrm{N}$ retained, $\% \mathrm{~N}$ intake & 9.93 & 9.46 & 9.32 & 9.27 & 0.07 & NS \\
\hline
\end{tabular}

Statistical analysis: L: Linear effect; NS: Not Significant; *: $p<0.05$; Means in the same row not sharing the same superscript are significantly different 


\section{DISCUSSION}

The present study with rumen-fistulated beef steers supports an earlier study in goats (Yuangklang et al., 2007) showing that replacement of soybean meal by dried tomato pomace raised the $\mathrm{pH}$ and ammonia concentration of ruminal fluid. An increase in ruminal $\mathrm{pH}$ may point at diminished fermentation and thus less bacterial protein synthesis. This would explain the observation in dairy cows that replacement of soybean meal by dried tomato pomace decreased milk protein concentration (Yuangklang et al., 2005). However, as discussed below the present data may be interpreted in various ways.

Increasing dietary levels of tomato pomace in the diet were associated with an increase in the $\mathrm{pH}$ of ruminal fluid, the effect being dose dependent in a linear fashion. Increasing amounts of dietary levels of tomato pomace of the ration went hand in hand with decreasing amounts of cassava chips and decreasing amounts of soybean meal. It could be suggested that the observed diet effect on ruminal $\mathrm{pH}$ was caused by changes in the dietary concentrations of cassava chips and soybean meal rather than those of tomato pomace. The starch in cassava chips is rapidly fermentable (Sommart et al., 2000; Nocek and Tamminga, 1991), whereas soybean meal might be more rapidly fermentable than tomato pomace (Yuangklang et al., 2006). According to this reasoning, the observed increase in ruminal $\mathrm{pH}$ is primarily related to the rate of fermentation rather than bacterial growth and protein synthesis. The possibility that there was no effect of dietary treatment on bacterial growth is supported by the finding that the number of ruminal bacteria was left unchanged.

The apparent digestibilities of NDF and ADF were not influenced by the composition of the ration. This may imply that the magnitude of rumen fermentation, or rather the number of ruminal bacteria was not influenced by the amount of tomato pomace in the ration, which was indeed found. However, the apparent, total gastro-intestinal tract digestibilities of NDF and ADF can be determined by fermentation in the hindgut (Owens et al., 2010). Diet effects on fermentation of NDF and ADF in the rumen could be negated by diet effects on fermentation in the hindgut. It could be suggested that increasing amounts of tomato pomace in the diet had reduced fermentation in the rumen, but stimulated that in the colon. This would then explain that apparent digestibility of NDF and ADF were not affected by the intake of tomato pomace, whereas apparent digestibility of crude protein was lowered by the rations containing tomato pomace. An increase in colonic fermentation and bacterial growth would raise the fecal excretion of nitrogen, which in turn would lower apparent total gastro-intestinal tract digestibility of crude protein (Heijnen and Beynen, 1997). However, it is difficult to see how an increased intake of tomato pomace would stimulate fermentation in the hindgut.

Increasing amounts of tomato pomace in the rations produced a dose-dependent rise in ruminal ammonia concentrations. This may be explained in part by the fact that increasing intakes of dried tomato pomace were associated with higher intakes of urea. In addition, the increase in ruminal ammonia indicates that the replacement of soybean meal by dried tomato pomace increased the amount of rumen degradable protein. In other words, the data are consistent with a higher fraction of the protein in tomato pomace being degradable than that in soybean meal. Earlier studies have also shown that dried tomato pomace contains protein that is degradable by rumen bacteria (Yuangklang et al., 2006). An increase in ruminal ammonia leads to an increase in blood ammonia which enhances ammonia uptake by the liver and subsequent conversion in urea (Gressley and Armentano, 2007). It was indeed found that the increase in rumen ammonia seen after the feeding of tomato pomace was associated with elevated blood urea concentrations. Contrary to what would be expected, the increase in blood urea concentrations went together with a decrease in urinary nitrogen excretion. It is suggested above that dried tomato pomace caused an increase in bacterial growth in the colon. High rates of colonic fermentation may be associated with high fluxes of urea from the blood into the hindgut, leading to less urinary excretion of nitrogen in the form of urea (Heijnen and Beynen, 1997; Gressley and Armentano, 2007). This would then explain that the feeding of tomato pomace caused a decrease in urinary nitrogen excretion.

\section{CONCLUSION}

This study with rumen-fistulated beef steers shows that the replacement of dietary soybean meal by dried tomato pomace had various effects on rumen fermentation and nitrogen metabolism. Increasing intakes of dried tomato pomace caused increasing ruminal $\mathrm{pH}$ values and ammonia concentrations and raised blood urea concentrations. The feeding of tomato pomace raised fecal nitrogen excretion and lowered urinary nitrogen excretion. We have attempted to explain and reconcile the observations, but must stress that we could only speculate. 


\section{REFERENCES}

Crocker, C.L., 1967. Rapid determination of urea nitrogen in serum or plasma without deproteinization. Am. J. Med. Technol., 33: 361-365. PMID: 6056194

Fondevila, M., J.A. Guada, J. Gasa and C. Castrillo, 1994. Tomato pomace as a protein supplement for growing lambs. Small Rum. Res., 13: 117-126. DOI: 10.1016/0921-4498(94)90086-8

Gressley, T.F. and L.E. Armentano, 2007. Effects of low rumen-degradable protein or abomasal fructan infusion on diet digestibility and urinary nitrogen excretion in lactating dairy cows. J. Dairy Sci., 90:1340-1353. PMID: 17297109

Heijnen, M.L. and A.C. Beynen, 1997. Consumption of retrograded (RS3) but not uncooked (RS2) resistant starch shifts nitrogen excretion from urine to feces in cannulated piglets. J. Nutr., 127: 1828-1832. PMID: 9278567

Hristov, A.N., M. Ivan, L.M. Rode and T.A. McAllister, 2000. Fermentation characteristics and ciliate populations in the rumen of cattle fed medium or high-concentrate barley-based diets. J. Anim. Sci. 79: 515-524. PMID: 11219463

Jansen, W.L., J. van der Kuilen, S.N. Geelen and A.C. Beynen, 2000. The effect of replacing nonstructural carbohydrates with soybean oil on the digestibility of fiber in trotting horses. Equine Vet. J., 32: 27-30. PMID: 10661381

Nocek, J. E. and S. Tamminga, 1991. Site of digestion of starch in the gastrointestinal tract of dairy cows and its effect on milk yield and composition. J. Dairy Sci. 74:3598-3629. PMID: 1744284

Owens, F.N., D.A. Sapienza and A.T. Hassen, 2010. Effect of nutrient composition of feeds on digestibility of organic matter by cattle: A review. J. Anim. Sci., 88: E151-169. PMID: 20081083

Purser, D.B. and R.J. Moir, 1966. Dietary effects upon concentrations of protozoa in the rumen. J. Anim. Sci., 25: 668-674. PMID: 4961306
Satter, L.D. and L.L. Slyter, 1974. Effect of ammonia concentration on rumen microbial protein production in vitro. Br. J. Nutr., 32: 199-208. PMID: 4472574

Sommart, K., M. Wanapat, P. Rowlinson, D.S. Parker and P. Climee et al., 2000. The use of cassava chips as an energy source for lactating dairy cows fed with rice straw. Asian-Australasian J. Anim. Sci., 13: 1094-1101.

Weiss, W.P., D.L. Frobose and M.E. Koch, 1997. Wet tomato pomace ensiled with corn plants for dairy cows. J. Dairy Sci., 80: 2896-2900. PMID: 9406082

Yuangklang, C., K. Vasupen, S. Wittayakun, C. Sarnklong and S. Wongsuthavas et al., 2005. Effect of substitution of soybean meal by dried tomato pomace on feed intake, digestibility, blood metabolites and milk production in lactating cows. In: New Dietary Strategies to Improve Health and Food Safety, Aiumlamia, S. and P. Rowlinson (Eds.), Khon Kaen, Thailand, ISBN: 0906562538, pp: 112-115.

Yuangklang, C., K. Vasupen, P. Srenanul, S. Wongsuthavas and J. Mitchaothai, 2006. Effect of utilization of dried tomato pomace as roughage source on feed intake, rumen fermentation and blood metabolites in beef cattle. Proceedings of the 44th Kasetsart University Annual Conference "Agricultural Science: Carrying Forward the Royal Bio-Energy Initiative, pp: 158-166.

Yuangklang, C., K. Vasupen, P. Srenanul, S. Wongsuthavas and J. Mitchaothai et al., 2007. Effect of substitution of soybean meal by dried tomato pomace on feed intake, rumen fermentation and nitrogen utilization in goats. Proceedings of the British Society of Animal Science, Southport, UK., pp: 240.

Zinn, R.A. and F.N. Owens, 1986. A rapid procedure for purine measurement and its use for estimating net ruminal protein synthesis. Can. J. Anim. Sci., 66: 157-166. 